\title{
River Capture and Freshwater Biological Evolution: A Review of Galaxiid Fish Vicariance
}

\author{
Jonathan M. Waters ${ }^{1, *(1)}$, Christopher P. Burridge ${ }^{2}\left(\mathbb{D}\right.$ and Dave Craw ${ }^{3}$ \\ 1 Department of Zoology, University of Otago, Dunedin 9016, New Zealand \\ 2 Discipline of Biological Sciences, School of Natural Sciences, University of Tasmania, Hobart 7001, Tasmania, \\ Australia; chris.burridge@utas.edu.au \\ 3 Department of Geology, University of Otago, PO Box 56, Dunedin 9016, New Zealand; \\ dave.craw@otago.ac.nz \\ * Correspondence: jon.waters@otago.ac.nz
}

Received: 13 May 2020; Accepted: 28 May 2020; Published: 29 May 2020

check for updates

\begin{abstract}
Geological processes can strongly affect the distribution and diversification of freshwater-limited species. In particular, a combination of geological and biological data has suggested that Earth history processes can drive vicariant isolation and speciation in non-migratory freshwater fishes. Here, we synthesise recently published geological and freshwater phylogeographic data to illustrate that changes in river drainage geometry are important drivers of galaxiid diversification, both in New Zealand and elsewhere. Major river capture events have led to the isolation and divergence of unique and geographically-restricted lineages, including taxa that are now of prime conservation concern. The parallel phylogeographic effects of drainage shifts have been verified by observations of concordant patterns in co-distributed species. Broadly, this study highlights the dynamic interplay between physical and biological processes in geologically active settings.
\end{abstract}

Keywords: biogeography; evolution; biodiversity; freshwater; river; phylogeography; geology

\section{Introduction}

Evolutionary researchers have long sought to establish the links between Earth history and biological processes [1-3]. Such interactions include the biological effects of major tectonic and climatic processes [4,5]. Although major Earth upheaval events can cause widespread elimination of biota, they can also underpin increased rates of biotic diversification [6]. While dramatic geological and climatic shifts can potentially impact a wide variety of ecosystems and species, recent research suggests that freshwater-limited biota, whose distributions are strongly restricted in spatial terms, can be particularly vulnerable. Along these lines, major shifts in river drainage geometry, such as river capture events (Bishop, 1995), are thought to have played important roles in the diversification of freshwater-limited species in many parts of the globe (e.g., Americas: [3,7,8], Africa: [9]), and may also go some way to explaining why freshwaters comprise only $0.1 \%$ of aquatic habitats, yet harbour $40 \%$ of fish species (Bloom et al. 2013) [10]. Such drainage alterations can evolve particularly swiftly in geologically dynamic settings such as New Zealand [6,11-18], but can also have substantial impacts even in tectonically stable settings such as Australia (e.g., $[19,20])$.

In recent decades, the application of genetic techniques in studies of freshwater biotas has revealed a wealth of previously cryptic species diversity (e.g., [21-23]). As a case in point, genetic and morphological research on New Zealand's Galaxias vulgaris complex has revealed at least 10 recently-evolved taxa (Figures 1 and 2) [21,24-29] within what was previously considered a single, widespread species [30]. While this diversity may potentially be explained by a variety of 
ecological and evolutionary processes, Earth history is likely a strong contributor to diversification of such lineages within geologically active regions such as New Zealand (Figures 1 and 2) [31].

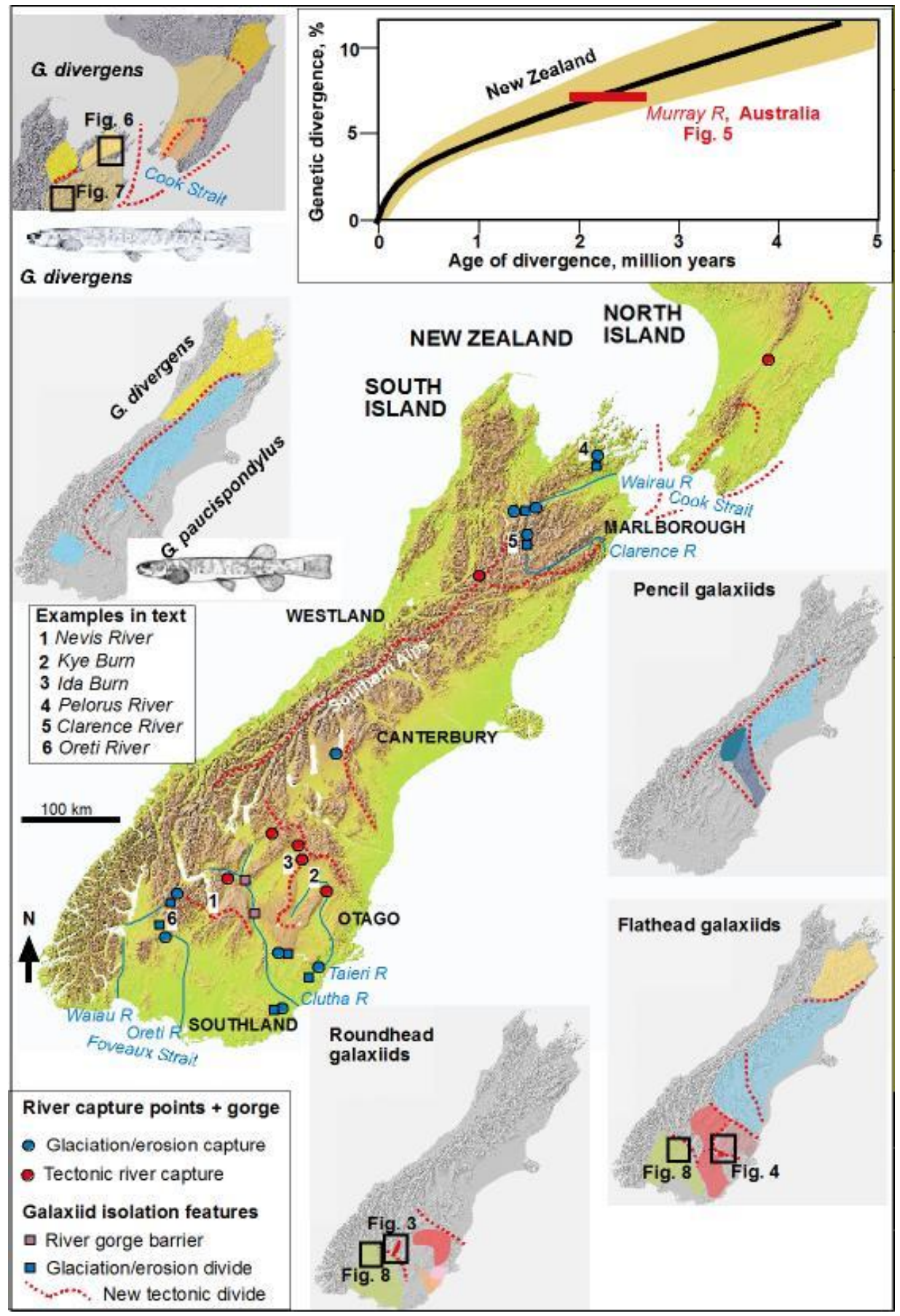

Figure 1. Biogeographic overview of New Zealand's freshwater-limited Galaxias, showing distributions of distinct species/lineages, and selected geological features linked to their diversification. Identities of 'roundhead' and flathead' lineages are indicated in Figure 2. A calibrated relationship between genetic divergence and geological age of separation (top) has been compiled by combining evidence across many of these river capture events. 

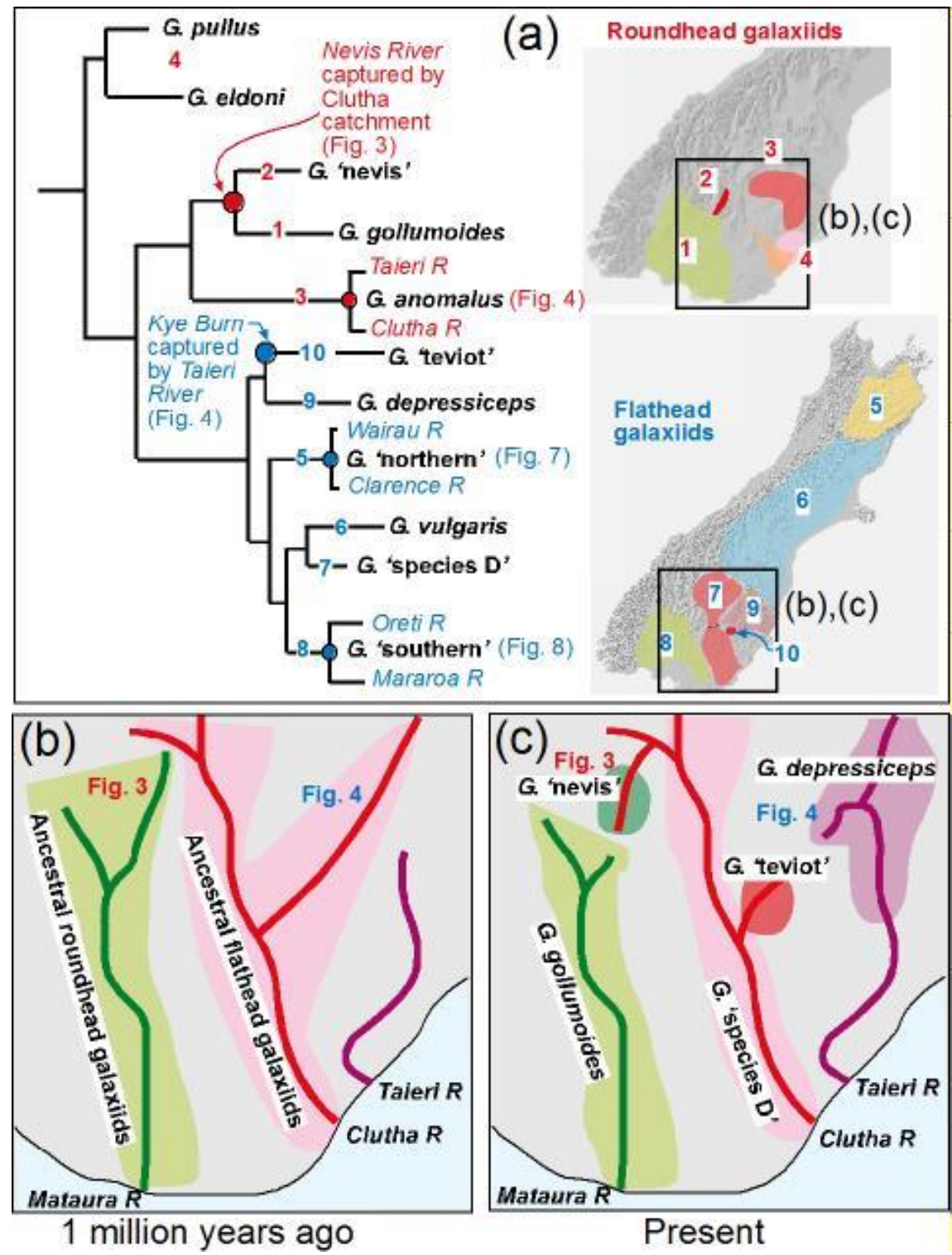

Figure 2. (a) Schematic phylogeny and phylogeography of the Galaxias vulgaris complex (South Island, New Zealand) modified and simplified from Waters, Rowe, Burridge and Wallis [29]. The tree shows interspecific and selected intraspecific divergences related to river capture events discussed in the text. The combined monophyly of Galaxias gollumoides and Galaxias 'nevis', as shown here, is supported by all markers analysed by Waters, Rowe, Burridge and Wallis [29], with the exception of RAG-1. (b) and (c) Schematic illustration of key river capture events linked to the divergence of Teviot and Nevis river galaxiids in southern South Island, New Zealand.

Here, we synthesise recent literature highlighting the tight links between Earth history and freshwater biological diversification, with a particular focus on the evolution of Galaxias fishes of the Southern Hemisphere. We focus primarily (but not exclusively) on New Zealand (Figures 1 and 2), where a combination of geographic isolation, active geology, and moderate effects of glaciation has underpinned a highly informative system for assessing relationships between geological processes and biological evolution [32]. Most of the phylogeographic and phylogenetic findings reviewed here are derived primarily from mitochondrial DNA sequences, although several of the studies also include multilocus nuclear data [29]. 


\section{The Evolution of New Zealand Landscapes}

New Zealand landscapes have been evolving in a dynamic tectonic environment for the past 20 million years, resulting in formation of a prominent axial mountain range, the Southern Alps, and associated lower ranges (Figure 1). The regionally varying geometry of the plate tectonic processes, combined with the varying nature of underlying basement rocks, has resulted in starkly differing landscapes in different areas of the landmass (Figure 1). Canterbury and Southland have comparatively simple landscapes, with large rivers draining greywacke mountains onto broad gravel plains (Figure 1). In contrast, Otago landscape is dominated by faulted folds of schist basement rocks, and Marlborough is made up of long narrow faulted greywacke ridges and valleys (Figure 1). The opening of Cook Strait approximately 1 million years ago separated the two main islands (Figure 1) [33]. Glaciation in the mountains and associated valleys has superimposed additional changes on these tectonic landscapes. Tectonic processes (millimetres/year or less) are relatively slow compared to glacial processes (metres per year or more), but the former typically have more substantial long-term effects on landscape than the latter.

This dynamic geological history has had profound effects on the evolution of freshwater fish (Figures 1 and 2). The contrasting geological and geomorphological characteristics among regions (see above) have led to contrasting levels of fish population connectivity within rivers [34]. Both tectonic and glacial processes have also progressively altered river drainage geometry, with numerous river capture events isolating and diversifying fish populations (Figures 1 and 2). The extent of fish diversity varies across the landscape because of the contrasting geological histories of the different regions (Figure 1). The rise of the Southern Alps in the Pliocene, for instance, resulted in broad, vicariant separation of Galaxias paucispondylus in the east and Galaxias divergens in the west (Figure 1) [32]. Similarly, the long-term evolution of different species and species groups such as 'pencil galaxiids' and 'flathead galaxiids' is predominantly the effect of the tectonic development of new drainage divides (Figure 1). In contrast, glaciation has affected specific valleys in complex but minor ways, and some of these events have caused local isolation of fish populations as well. Examples of these contrasting processes, with differing spatial and time scales, are outlined below.

\section{Freshwater Phylogeographic Anomalies: the Biological Legacy of River Capture}

Over the last two decades, combined analyses of galaxiid fish phylogeography and associated river geology have revealed landmark examples of the evolutionary effects of drainage rearrangement (Figure 1). In each of the examples outlined below, large-scale shifts in drainage geometry effectively isolated previously connected populations, with marooned lineages subsequently diverging and/or speciating in isolation. In each of the cases listed below, the geological evidence for shifts in drainage geometry is independent of biology, while the biogeographic evidence is similarly self-sufficient. However, the combination of these data sets yields highly complementary perspectives, effectively enhancing the combined interpretation of each case as whole.

\subsection{Nevis River Capture-Isolation of the Nevis Galaxiid}

The Nevis River, currently a major tributary of the Kawarau Gorge, drains north into the Clutha River system, yet houses a unique and divergent 'roundhead' galaxiid lineage (Galaxias 'nevis') most closely related to the 'Southland' species Galaxias gollumoides, but clearly distinct from all other nearby Galaxias in the Clutha system [31]. Geological evidence and landscape features indicate that the Nevis previously flowed south in the Nokomai branch of the Mataura River (Southland) until the mid-late Pleistocene (300-500 ka; Figure 3), when the tectonically mediated reversal of the Nevis effectively marooned the now unique Nevis galaxiid in this isolated Clutha tributary (Figure 2b,c). Key geological evidence comes from fault geometry, petrology of anomalous Nokomai River sediments, and the recently-formed lower Nevis gorge (Figure 3). The unique Nevis clade has extremely high conservation value and is now widely considered to be worthy of distinct species status $[35,36]$. Two additional 
populations of G. gollumoides have been found in the Clutha system, reflecting additional changes in drainage geometry with neighbouring catchments, such that these processes have been more influential for the distribution of G. gollumoides in the Clutha than fish movement within this catchment itself $[13,37]$.

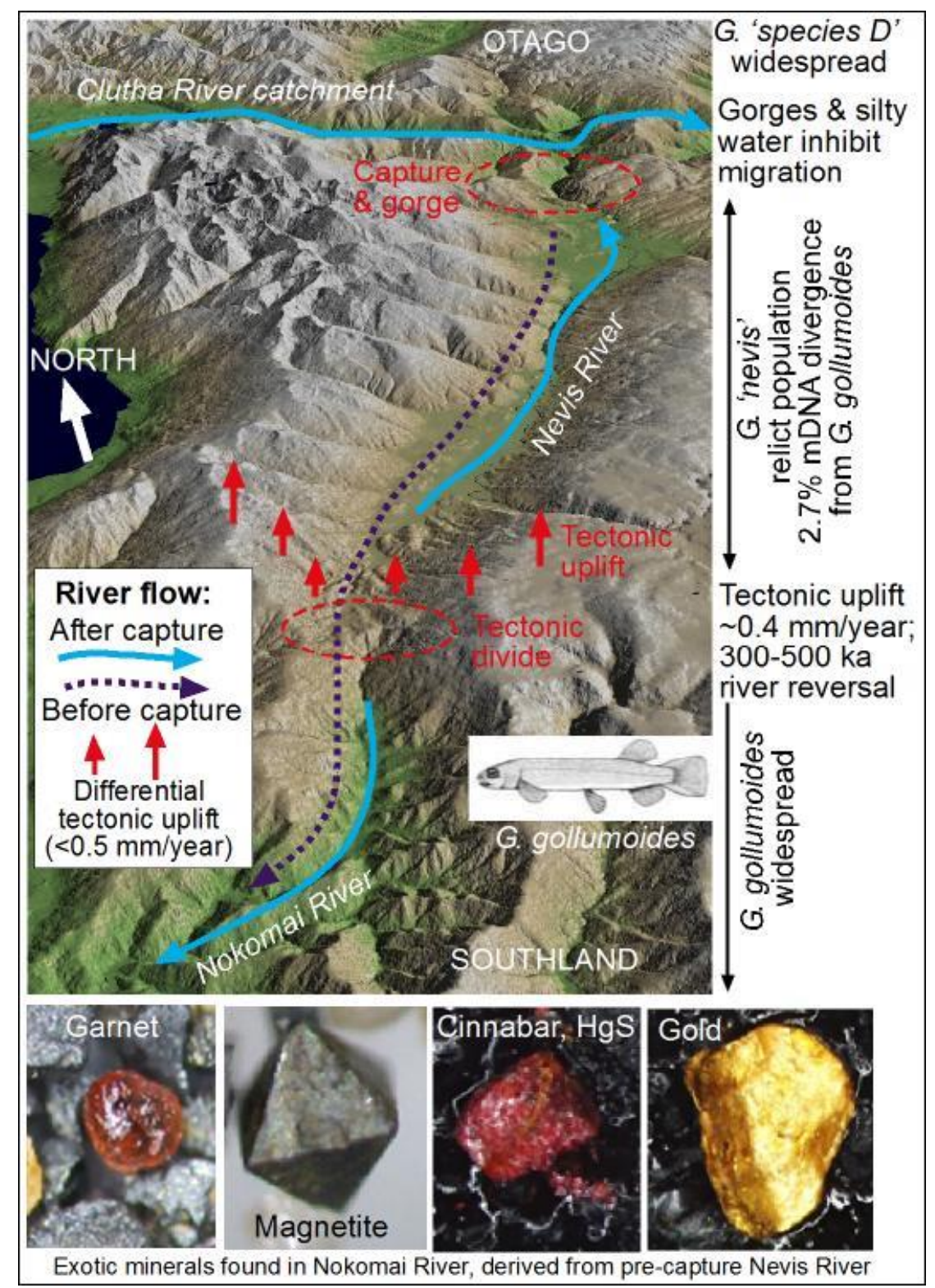

Figure 3. Mid-late Pleistocene reversal of the Nevis River, Central Otago, led to the isolation and divergence of the distinctive Nevis galaxiid (G. 'nevis'), sister to the 'Southland' species G. gollumoides, thus generating a persisting biogeographic anomaly within the Clutha River system (Figures 1 and 2). Exotic minerals present in the Nokomai River highlight its former connection with the Clutha system.

\subsection{Capture of the Kye Burn-Isolation of the Teviot Galaxiid}

The Taieri River of southeastern South Island has a dynamic Quaternary history that has led to a modern-day biogeographic disjunction, with distinct upper Taieri (Galaxias depressiceps, Galaxias anomalus) versus lower Taieri (Galaxias eldoni, Galaxias pullus) non-migratory galaxiid faunas (Figure 2; 4a). The circuitous path of the modern Taieri, circumnavigating the recently uplifted Rock and Pillar Range (Figure 4a), resulted from the mid-Pleistocene capture of the Kye Burn (previously Clutha catchment) by the proto-Taieri (Figure 4a) [15]. This reversal of the Kye Burn apparently severed the 
ancestral distribution of $G$. depressiceps, and led to the isolation and divergence of the now unique Teviot galaxiid (Figure 2b,c) which, like the Nevis galaxiid (above), has high conservation value and is widely considered to be worthy of formal taxonomic distinction [35,36]. This case demonstrates how river capture can generate new species diversity. Furthermore, while instream features (e.g., gorges) may have contributed to the maintenance of biogeographic disjunctions such as that observed within the Taieri (Figure 2), such features were not necessarily the initiators of such disjunctions, and may be falsely invoked when changes to drainage geometry have not been considered.

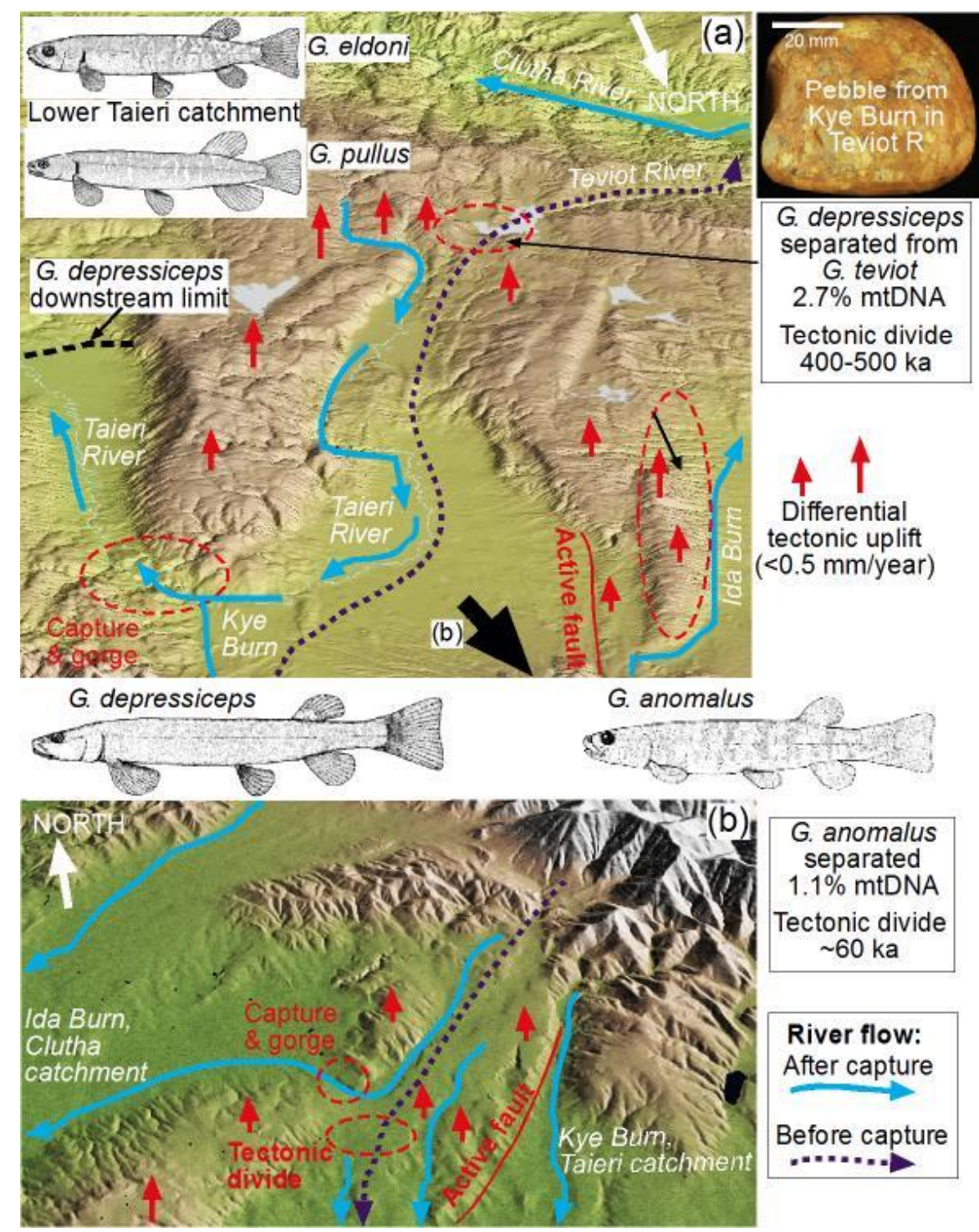

Figure 4. (a) Late Pleistocene-recent tectonic compression uplifted folded mountain ranges that now define the boundaries between Taieri and Clutha River catchments in Otago (Figure 1) [6,15]. This uplift led to capture of the Kye Burn river (formerly part of the Teviot-Clutha system) by the proto-Taieri River, and simultaneously led to isolation and divergence of the Teviot River galaxiid (Galaxias 'teviot') and Taieri River Galaxias depressiceps from a common 'flathead' ancestor. This composite origin of the Taieri River is also reflected in a modern-day biogeographic disjunction between upper Taieri (G. depressiceps, Galaxias anomalus) versus lower Taieri (Galaxias eldoni, Galaxias pullus) galaxiid assemblages. (b) More recent ( 60 ka) tectonic uplift along a fault in the same area has diverted the Ida Burn from the Kye Burn-Taieri River catchment to the Clutha catchment, isolating G. anomalus populations across a new divide. 
The precise tectonic processes that led to the drainage reversal of the Kye Burn (this example) and the Nevis-Nokomai example (above) are not determinable now because of subsequent erosion of evidence. However, an indication of the kinds of tectonic activity can be gleaned from a relatively young example that affected the Kye Burn catchment (Figure $4 \mathrm{~b}$ ). In this analogous case, the Ida Burn originally flowed southeastwards into the Kye Burn until a fault uplifted a new divide and diverted the Ida Burn westwards, forcing it to erode through a rising basement ridge (Figure $4 \mathrm{~b}$ ). Clutha and Taieri populations of $G$. anomalus were isolated across this new divide and are now genetically distinct after $\sim 60 \mathrm{ka}$ of separation (Figure $4 \mathrm{~b}$ ).

\subsection{Rerouting of Australia's Murray River Isolated the Glenelg River Fauna}

The Australian continent is tectonically stable compared to New Zealand, but still exhibits evidence of tectonically-driven river capture events shaping fish biodiversity [20]. In particular, the dramatic late Pliocene (2-3 Ma) re-routing of the vast Murray-Darling River system, which formerly reached the sea via the Douglas Depression through what is now the Glenelg River (Figure 5) [20,38], led to isolation and divergence of a distinctive Glenelg freshwater fauna (including lineages of Gadopsis, Galaxias and Cherax). Notably, an 'outlying' lineage of galaxias with a distribution centred on the Glenelg and nearby Wimmera rivers (Galaxias oliros) is sister to the rest of the speciose 'olidus' complex [22,23], and this early divergence likely reflects the Pliocene rerouting event (Figure 5) [20].
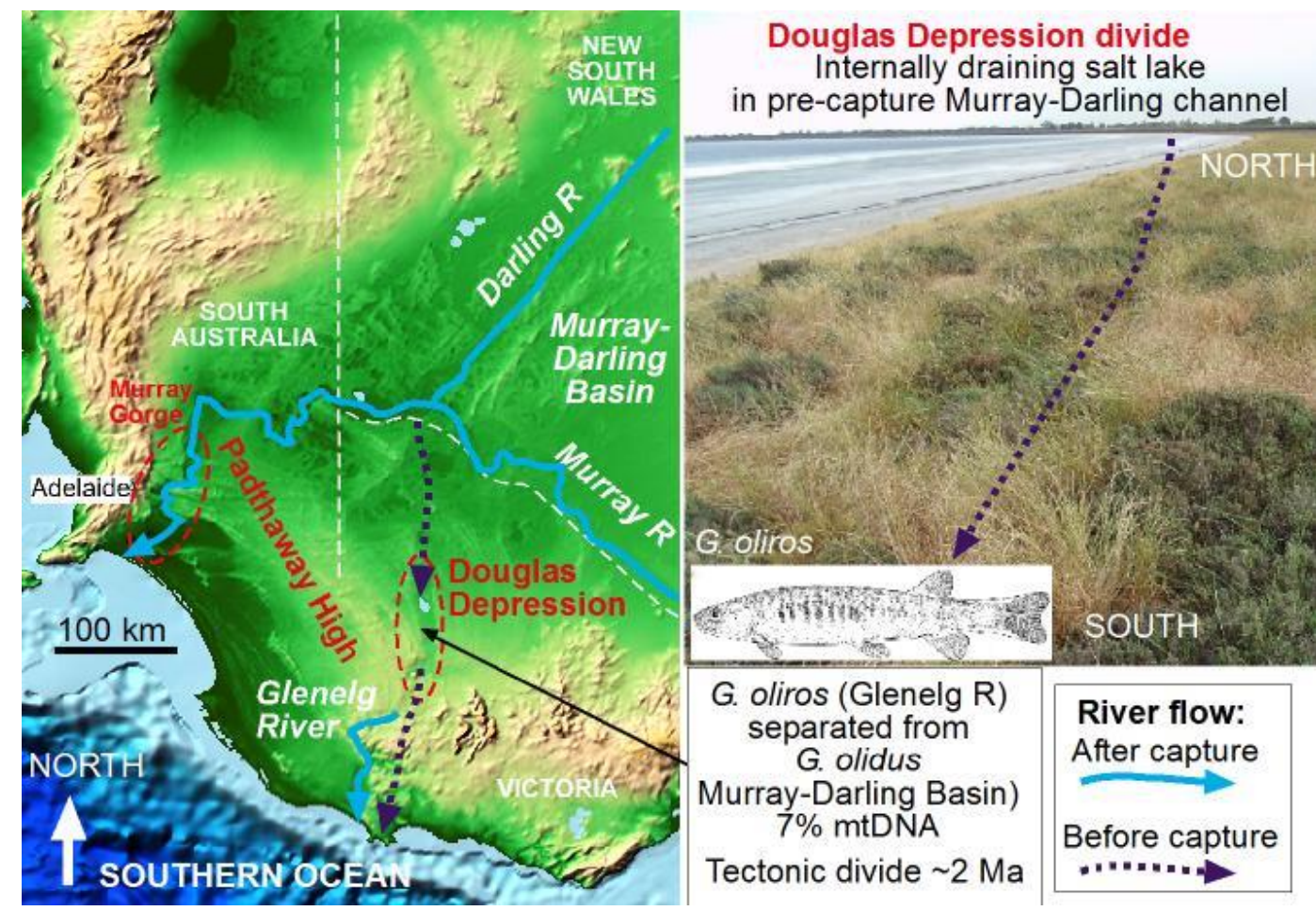

Figure 5. Slow tectonic processes, and therefore slow erosion, in southern Australia have permitted preservation of evidence of drainage reorientation in the lower reaches of the Murray-Darling River system. The river formerly discharged along a subtle tectonic feature, the Douglas Depression [38]. Uplift of a broad gentle warp, the Padthaway High, in the early Pleistocene halted this discharge channel, initially forming an inland lake until a new discharge channel formed at Murray Gorge. This drainage re-orientation is proposed to have isolated several freshwater lineage pairs, likely including the predominantly southwest Victorian Galaxias oliros which is sister to the remainder of the G. olidus complex [22], discussed in [20]. 


\section{River Vicariance Synchronises Population Divergence across Multiple Species}

Multispecies phylogeographic analyses of co-distributed species can provide powerful tests of ecosystem-wide evolutionary processes driven by Earth history, e.g., [5,39]. Similarly, observations of ecologically similar and closely related species increase the confidence of association between pattern and process 'phylogeographic parallelism'; sensu Kreger et al. [40]. Given that drainage evolution events can cause precise spatiotemporal disruption of freshwater connectivity, multispecies phylogeography of freshwater fishes should reveal shared evolutionary histories. Recent comparative genetic analyses of co-distributed fish species provide strong evidence for similar intraspecific effects of vicariance, as outlined below.

\subsection{Isolation of Pelorus-Kaituna}

Until the late Pleistocene, much of the Marlborough region of northern South Island New Zealand was dominated by a single large river system, encompassing the modern Wairau, Kaituna and Pelorus catchments (Figure 6) [41]. Specifically, the Pelorus River flowed south through the Kaituna valley into the Wairau valley. In the late Quaternary, however, the Kaituna reversed, to flow north into Pelorus Sound, splitting a once continuous drainage. This sundering of the proto-Wairau approximately $100 \mathrm{ka}$ [41] simultaneously isolated the Pelorus-Kaituna from the modern-day Wairau. Comparisons of genetic divergence among Pelorus-Kaituna and Wairau populations of both the dwarf galaxiid Galaxias divergens and the co-distributed eleotrid upland bully Gobiomorphus breviceps yield near-identical levels of intraspecific mtDNA divergence [16]. These findings highlight that disruption of drainage connections can lead to simultaneous disruption of phylogeographic connectivity among co-distributed species, and the detection of similar genetic divergences across these independent taxa provides strong evidence for this role of vicariant processes in shaping freshwater fish evolution.

\subsection{Capture of Upper Clarence}

The headwaters of two major drainages in northeastern South Island, the Wairau and Clarence Rivers, were linked by Pleistocene glaciations (Figure 7). Specifically, the upper Wairau system formerly drained into the Alma River in the upper Clarence, prior to the last glacial retreat. These recent headwater connections are highlighted by the genetic similarity of Clarence and Wairau populations of two co-distributed galaxiids (G. divergens, G. vulgaris 'northern') relative to those of the geographically intermediate Awatere River [12]. The near-identical mtDNA divergences ( $0.2 \%$ sequence divergence) between Wairau and Clarence populations of both taxa emphasises the simultaneous divergence initiated by this vicariant isolation event (Figure 7) [12]. However, a third species, the upland bully Gobiomorphus breviceps, did not reveal concordant patterns. It was hypothesised that the drainage re-arrangement mediated range expansions in the two galaxiids, while the bully was already represented in both systems, such that genetic impacts were muted for this species (see 'founder takes all'; below). From these findings, it was inferred that river capture processes are perhaps most likely to impact fish phylogeography when they lead to expansion of a lineage's range, as opposed to the mixture of lineages with an existing range. 


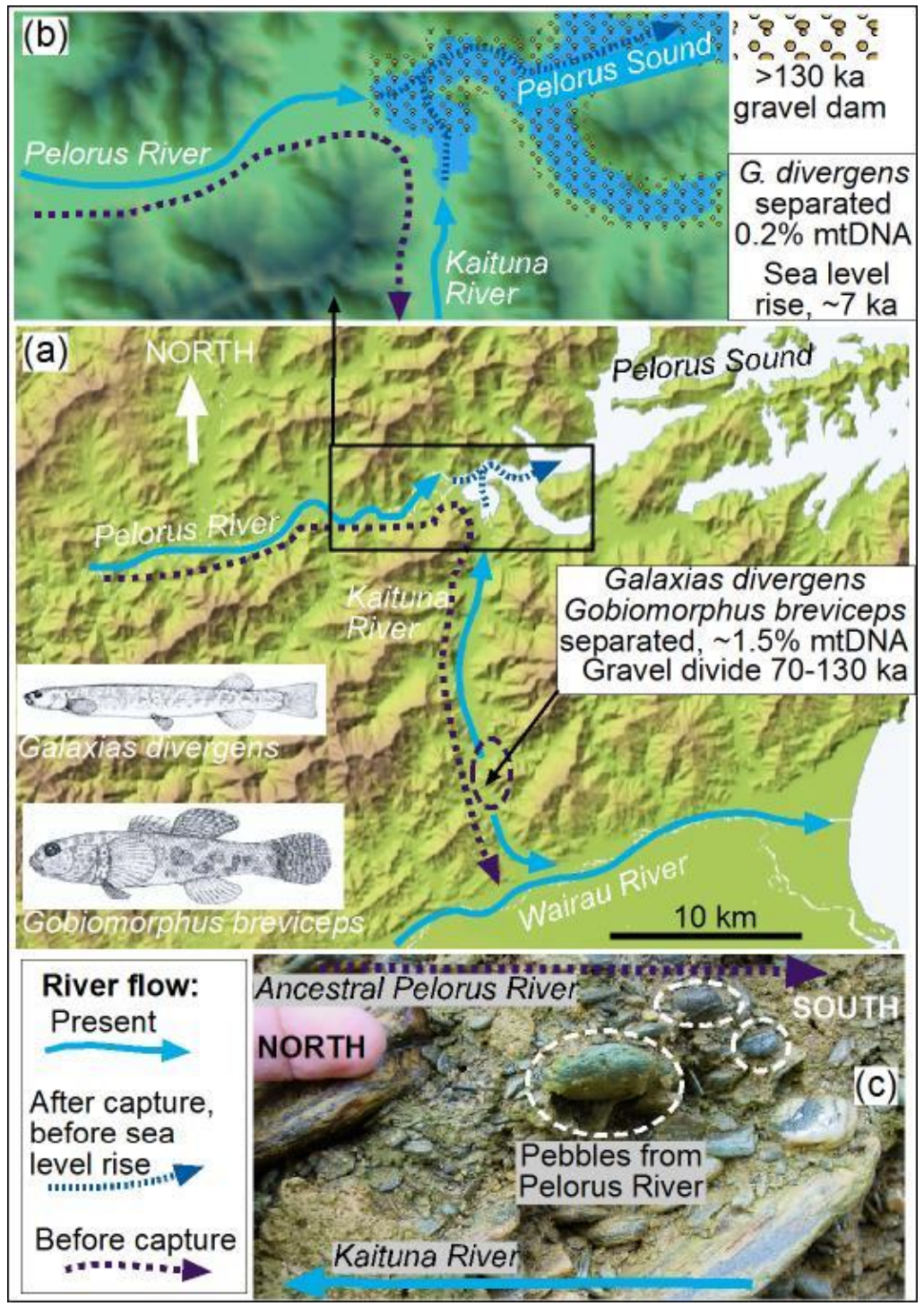

Figure 6. Mid-late Pleistocene glacial outwash from the Pelorus River (Marlborough Sounds) formed a gravel dam in what is now Pelorus Sound $(\mathbf{a}, \mathbf{b})$, a drowned river valley. This dam diverted the Pelorus River to the south $(\mathbf{a}, \mathbf{b})$ to transport distinctive pebbles towards the Wairau River (c) [41]. When the Pelorus Sound dam was breached in late Pleistocene, drainage reversal formed the north-flowing Kaituna River and separated Pelorus-Kaituna populations of Galaxias divergens from their Wairau River (Figure 1) relatives [16]. Holocene sea-level rise subsequently separated Kaituna River from Pelorus River, isolating their populations of $G$. divergens. Similar divergences are present in the co-distributed upland bully Gobiomorphus breviceps [16]. 


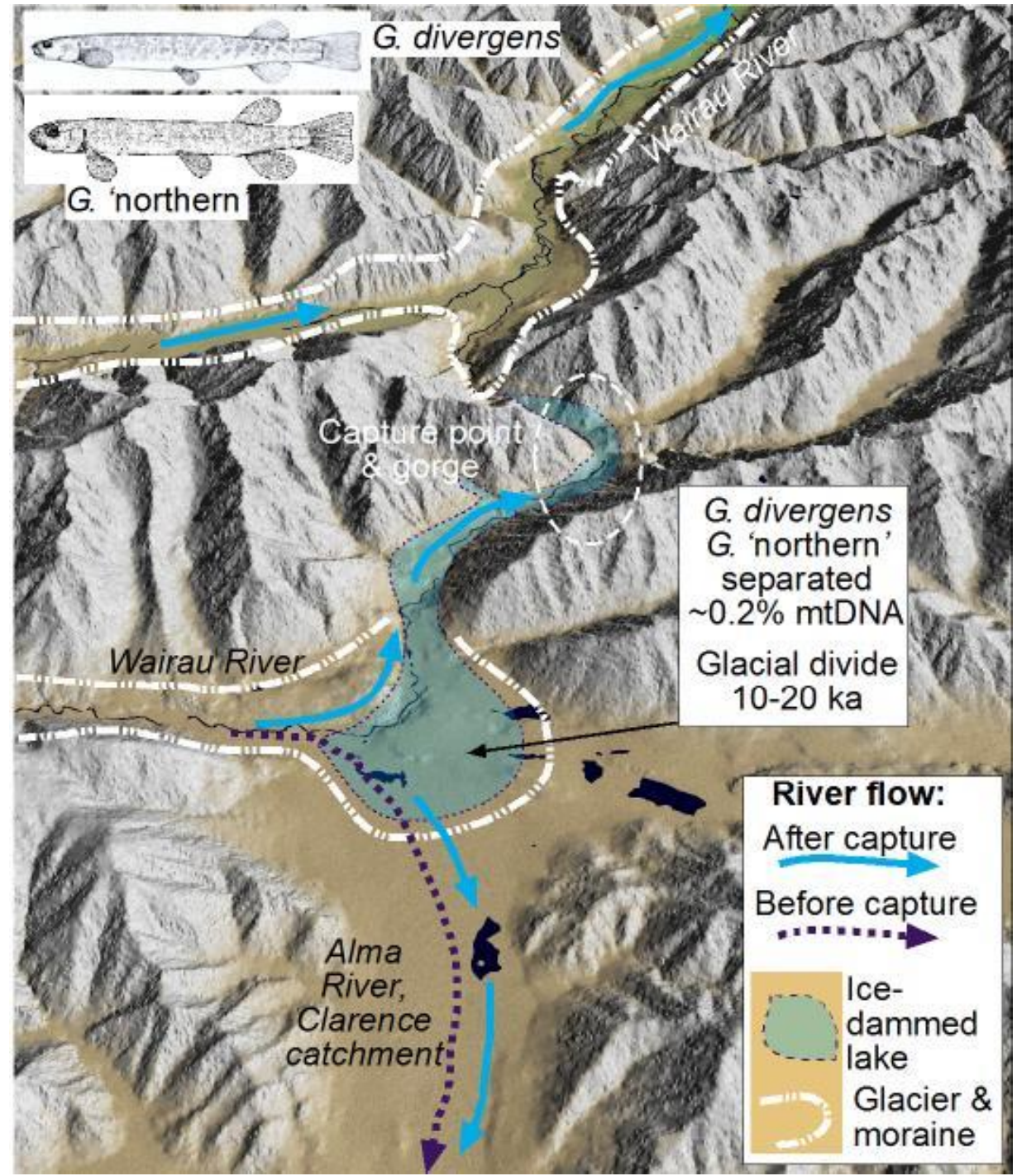

Figure 7. Headwaters of two major drainages in inland Marlborough, the Wairau and Clarence Rivers (Figure 1), were linked by glaciers and a glacial lake during the late Pleistocene. These links facilitated genetic exchange among populations of two co-distributed Galaxias species (G. divergens, G. vulgaris 'northern') until their populations were severed during the last glacial retreat. These headwater connections are highlighted by the similarity of Clarence and Wairau populations relative to those of the geographically intermediate Awatere River [12].

\subsection{Isolation of Von-Oreti}

The Von River, Southland, currently flows north into Lake Wakatipu, part of the vast Clutha catchment (Figures 1 and $8 \mathrm{a}, \mathrm{b}$ ). During Pleistocene glaciations, glacial ice extended south from Lake Wakatipu into the headwaters of the Oreti River, and discharged abundant outwash gravel southwards. These southward periods of flow discharged to Foveaux Strait, either via what is now the lower Oreti River, or via the neighbouring Mararoa/Waiau valley system (Figures 1 and 8a). The divide between these two latter rivers is low and formed by glacial outwash gravels of various ages (Figure 8a). The present geometry of the Oreti-Waiau divide has apparently been in place for more than $140 \mathrm{ka}$, as indicated by geological dating of the lowest gravel levels [11]. 


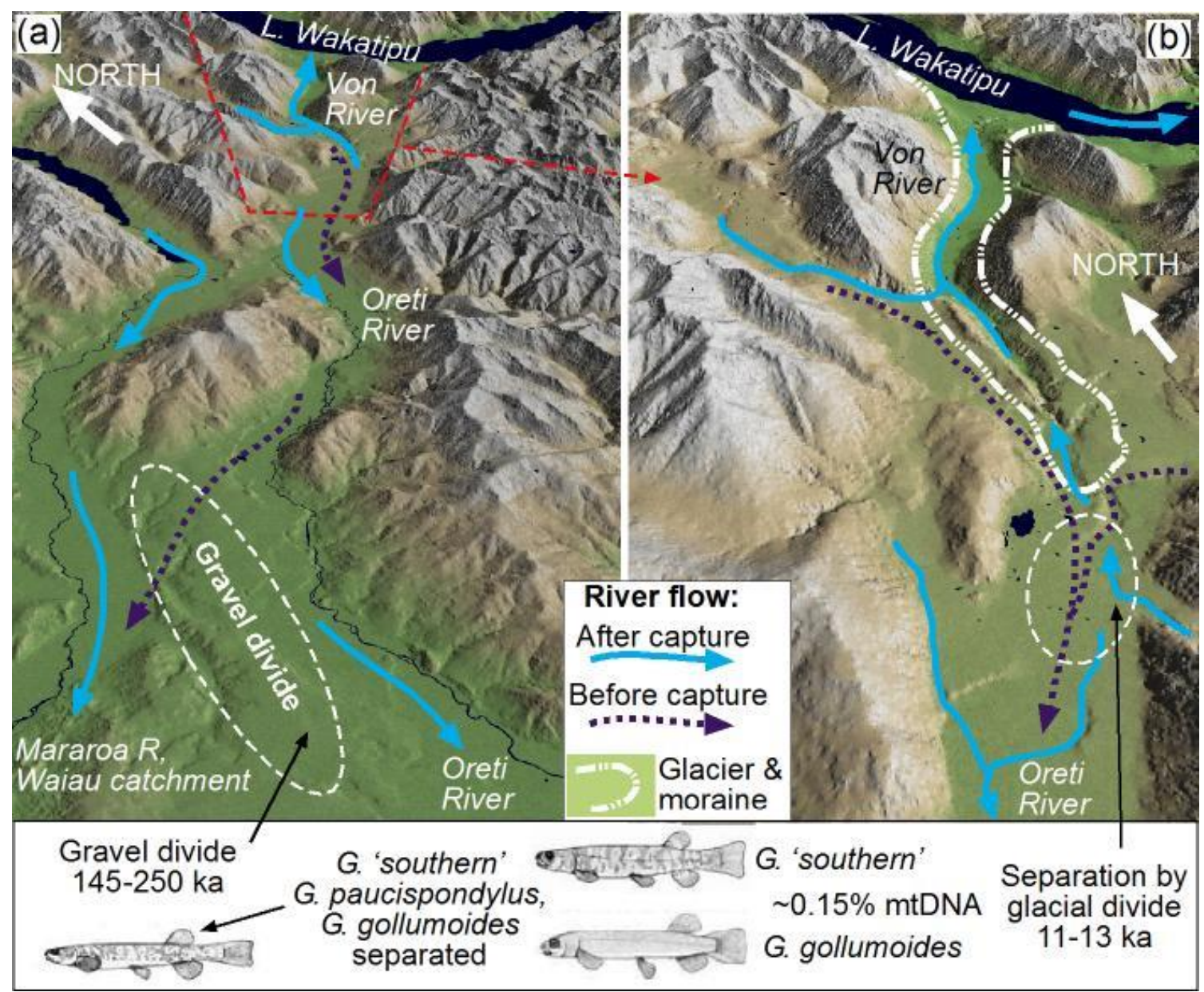

Figure 8. (a) Late Pleistocene glacial outwash formed a gravel divide between two major rivers in Western Southland, separating populations of three galaxiid species. (b) River re-orientation at the head of the Oreti River (Figure 1) was driven by glaciation extending up the Von valley from Lake Wakatipu. Subsequent early Holocene glacial retreat separated populations of Galaxias 'southern' and Galaxias gollumoides into Oreti and Von Rivers.

Formation of this divide between the Oreti and Mararoa rivers initiated parallel genetic divergence of three co-distributed freshwater-limited galaxiids: G. 'southern', G. gollumoides, and G. paucispondylus (Figure 8a). Interestingly, reciprocal monophyly of mitochondrial lineages was lacking in G. gollumoides, as some Oreti haplotypes were more closely related to Mararoa haplotypes than they were to other Oreti haplotypes. While such relationships may refute river capture for the present-day distribution and divergence of populations, and perhaps suggest more recent movement between catchments involving 'wet connections' or anastomosing of catchments during low sea stands [17], incomplete lineage sorting under complete isolation is also possible. In this instance, statistical phylogeography [42], involving coalescent simulations, could not reject a history of complete isolation for Oreti and Mararoa G. gollumoides following 145-240 ky of isolation [11]. In contrast, post-capture genetic connectivity could not be rejected for a fourth species, the upland bully Gobiomorphus breviceps [11]. Cases of incomplete lineage sorting are more likely for more recent events, e.g., [13,16], and particularly when population sizes are large.

A relatively young southern connection between Von River and the Oreti catchment is highlighted by the presence of G. 'southern' and another typical Southland species, G. gollumoides, in the Von River (Figures 1 and $8 \mathrm{~b}$ ). The very recent connectivity between the Von and Southland drainages is highlighted by the shallow genetic divergences in both taxa (Figure 8b) $[11,13]$. 


\section{Discussion and Conclusions}

\subsection{Persistence of Biological Signatures of River Capture}

Our studies of galaxiid phylogeography highlight the lasting genetic and biogeographic signatures of ancient drainage evolution events. One could reasonably ask why such ancient signatures have not been overwritten by more recent dispersal events and geneflow? One possible reason for the continued localised distributions of river capture relict lineages such as Teviot [15] and Nevis [31] galaxiids involves the ecologically inhospitable gorges in the Clutha and Taieri rivers (see $[13,15])$ that may have prevented subsequent range expansion of these outliers. In some instances, these same instream features may have inhibited colonisation by invasive species that threaten native galaxiids (trout) [43]. Additionally, it is possible that adaptive processes (competitive exclusion) and density-dependent factors ('founder-takes-all', high-density blocking; see [44,45]) have prevented established lineages from infiltrating the geographic ranges of one another.

Based on the studies summarised above, we also propose that the biological effects of such drainage evolution events may depend on their geographic context: capture events occurring on the periphery of a drainage or species range may leave particularly lasting biological signals, as opposed to those operating within the existing range of a species [12]. Furthermore, in some instances, the distribution of a species within a catchment may reflect multiple changes to drainage geometry involving neighbouring catchments, rather than movement within a catchment [37]. Finally, while the presence of biogeographic disjunctions within a catchment may be reinforced by instream barriers, such barriers may not have initiated the disjunction and could be falsely invoked if alterations to drainage geometry are not considered.

\subsection{Links between Geological and Genetic Change}

Our research assessing links between galaxiid phylogeography and geologically-constrained freshwater isolation events have provided a robust context for assessing rates of genetic change $[16,18,46]$. The availability of accurately-dated capture events similarly presents a strong system for calibrating rates of molecular evolution in freshwater-limited fishes, and the application of this framework has yielded an internally-consistent series of genetic divergences and geological ages (Figure 1). These data also open up the possibility of using fish genetics to date geological events in regions where the geological record is incomplete [18].

On the basis of studies reviewed here, we conclude that changes in river drainage geometry represent important drivers of non-migratory galaxiid diversification, both in New Zealand and elsewhere. Specifically, major river capture events have led to the isolation and divergence of unique and geographically-restricted lineages, including taxa that are now of prime conservation concern. Additionally, the concerted evolutionary effects of drainage shifts have been verified by observations of concordant patterns in co-distributed species (phylogeographic parallelism).

In the majority of studies reviewed here, congruence between genetic relationships and geological history was clearly evident, even for events as young as $\sim 20 \mathrm{kya}$. In some cases, the extent of congruence between genetics and geology has been further scrutinised in the context of coalescent processes, using simulation approaches to accommodate the influences of population size and time (e.g., [11]) in explaining the extent of lineage sorting and genetic divergence. Understanding the timeframe over which such diverging populations are expected to evolve reciprocal monophyly is important when interpreting such links between biological and geological processes [16].

The study of freshwater vicariance in a geological context has potentially broad evolutionary relevance due to the potential for calibrating rates of DNA evolution when geological ages are known [46], and likewise for estimating the timeframe of geological change when molecular rates are well calibrated [18]. When considered together, evolutionary analyses of rivers and their biotas lead to a form of reciprocal illumination, enhancing both biological and geological sciences. 
Author Contributions: Conceptualization, J.M.W., D.C. and C.P.B.; Figures, D.C.; Original Draft, J.M.W.; Review and Editing, D.C. and C.P.B.; Funding Acquisition, J.M.W. and D.C. All authors have read and agreed to the published version of the manuscript.

Funding: This research was funded by the Marsden Fund, administered by the Royal Society of New Zealand, (grant numbers UOO705 and UOO0404).

Acknowledgments: Research reviewed here was funded by the University of Otago, and the Marsden Fund. We thank all the collaborators who contributed to the work synthesised here. Particular thanks are due to Graham Wallis, Richard Allibone, Tania King, and the late Bob McDowall for their foundational work on galaxiid systematics and biogeography. Luke Easterbrook-Clarke (University of Otago) and Roger Smith (Geographx.co.nz) assisted with geographical images.

Conflicts of Interest: The authors declare no conflict of interest.

\section{References}

1. Hewitt, G.M. The genetic legacy of the Quaternary ice ages. Nature 2000, 405, 907-913. [CrossRef]

2. Riddle, B.R.; Hafner, D.J.; Alexander, L.F.; Jaeger, J.R. Cryptic vicariance in the historical assembly of a Baja California Peninsular desert biota. Proc. Natl. Acad. Sci. USA 2000, 97, 14438-14443. [CrossRef] [PubMed]

3. Mayden, R.L. Vicariance biogeography, parsimony, and evolution in North American freshwater fishes. Syst. Zool. 1988, 37, 329-355. [CrossRef]

4. Knowlton, N.; Weigt, L.A. New dates and new rates for divergence across the Isthmus of Panama. Proc. R. Soc. Lond., Ser. B: Biol. Sci. 1998, 265, 2257. [CrossRef]

5. Wallis, G.P.; Waters, J.M.; Upton, P.; Craw, D. Transverse alpine speciation driven by glaciation. Trends Ecol. Evol. 2016, 31, 916-926. [CrossRef] [PubMed]

6. Craw, D.; Craw, L.; Burridge, C.P.; Wallis, G.P.; Waters, J.M. Evolution of the Taieri River catchment, East Otago, New Zealand. N. Z. J. Geol. Geophys. 2016, 59, 257-273. [CrossRef]

7. Kozak, K.H.; Blaine, R.A.; Larson, A. Gene lineages and eastern North American palaeodrainage basins: Phylogeography and speciation in salamanders of the Eurycea bislineata species complex. Mol. Ecol. 2006, 15, 191-207. [CrossRef]

8. Zemlak, T.S.; Habit, E.M.; Walde, S.J.; Battini, M.A.; Adams, E.D.M.; Ruzzante, D.E. Across the southern Andes on fin: Glacial refugia, drainage reversals and a secondary contact zone revealed by the phylogeographical signal of Galaxias platei in Patagonia. Mol. Ecol. 2008, 17, 5049-5061. [CrossRef]

9. Goodier, S.A.M.; Cotterill, F.P.D.; O'Ryan, C.; Skelton, P.H.; de Wit, M.J. Cryptic diversity of African tigerfish (genus Hydrocynus) reveals palaeogeographic signatures of linked Neogene geotectonic events. PLoS ONE 2011, 6, e28775. [CrossRef]

10. Bloom, D.D.; Weir, J.T.; Piller, K.R.; Lovejoy, N.R. Do freshwater fishes diversify faster than marine fishes? A test using state-dependent diversification analyses and molecular phylogenetics of new world silversides (Atherinopsidae). Evolution 2013, 67, 2040-2057. [CrossRef]

11. Burridge, C.P.; Craw, D.; Jack, D.C.; King, T.M.; Waters, J.M. Does fish ecology predict dispersal across a river drainage divide? Evolution 2008, 62, 1484-1499. [CrossRef] [PubMed]

12. Burridge, C.P.; Craw, D.; Waters, J.M. River capture, range expansion, and cladogenesis: The genetic signature of freshwater vicariance. Evolution 2006, 60, 1038-1049. [CrossRef] [PubMed]

13. Burridge, C.P.; Craw, D.; Waters, J.M. An empirical test of freshwater vicariance via river capture. Mol. Ecol. 2007, 16, 1883-1895. [CrossRef] [PubMed]

14. Waters, J.M.; Wallis, G.P. Cladogenesis and loss of the marine life-history phase in freshwater galaxiid fishes (Osmeriformes: Galaxiidae). Evolution 2001, 55, 587-597. [CrossRef]

15. Waters, J.M.; Wallis, G.P.; Burridge, C.P.; Craw, D. Geology shapes biogeography: Quaternary river-capture explains New Zealand's biologically 'composite' Taieri River. Quat. Sci. Rev. 2015, 120, 47-56. [CrossRef]

16. Waters, J.M.; Rowe, D.L.; Apte, S.; King, T.M.; Wallis, G.P.; Anderson, L.; Norris, R.J.; Craw, D.; Burridge, C.P. Geological dates and molecular rates: Rapid divergence of rivers and their biotas. Syst. Biol. 2007, 56, 271-282. [CrossRef] [PubMed]

17. Craw, D.; Burridge, C.; Anderson, L.; Waters, J.M. Late Quaternary river drainage and fish evolution, Southland, New Zealand. Geomorphology 2007, 84, 98-110. [CrossRef]

18. Craw, D.; Burridge, C.; Norris, R.; Waters, J. Genetic ages for Quaternary topographic evolution: A new dating tool. Geology 2008, 36, 19-22. [CrossRef] 
19. Hurwood, D.A.; Hughes, J.M. Phylogeography of the freshwater fish, Mogurnda adspersa, in streams of northeastern Queensland, Australia: Evidence for altered drainage patterns. Mol. Ecol. 1998, 7, 1507-1517. [CrossRef]

20. Waters, J.M.; Burridge, C.P.; Craw, D. The lasting biological signature of Pliocene tectonics: Reviewing the re-routing of Australia's largest river drainage system. J. Biogeogr. 2019, 46, 1494-1503. [CrossRef]

21. Waters, J.M.; Wallis, G.P. Mitochondrial DNA phylogenetics of the Galaxias vulgaris complex from South Island, New Zealand: Rapid radiation of a species flock. J. Fish. Biol. 2001, 58, 1166-1180. [CrossRef]

22. Adams, M.; Raadik, T.A.; Burridge, C.P.; Georges, A. Global biodiversity assessment and hyper-cryptic species complexes: More than one species of elephant in the room? Syst. Biol. 2014, 63, 518-533. [CrossRef] [PubMed]

23. Raadik, T.A. Fifteen from one: A revision of the Galaxias olidus Günther, 1866 complex (Teleostei, Galaxiidae) in south-eastern Australia recognises three previously described taxa and describes 12 new species. Zootaxa 2014, 3898, 1-198. [CrossRef] [PubMed]

24. Allibone, R.M.; Wallis, G.P. Genetic variation and diadromy in some native New Zealand galaxiids (Teleostei, Galaxiidae). Biol. J. Linn. Soc. 1993, 50, 19-33. [CrossRef]

25. Allibone, R.M.; Crowl, T.A.; Holmes, J.M.; King, T.M.; McDowall, R.M.; Townsend, C.R.; Wallis, G.P. Isozyme analysis of Galaxias species (Teleostei: Galaxiidae) from the Taieri River, South Island, New Zealand: A species complex revealed. Biol. J. Linn. Soc. 2008, 57, 107-127. [CrossRef]

26. McDowall, R.M.; Wallis, G.P. Description and redescription of Galaxias species (Teleostei: Galaxiidae) from Otago and Southland. J. R. Soc. N. Z. 1996, 26, 401-427. [CrossRef]

27. McDowall, R.M. Two further new species of Galaxias (Teleostei: Galaxiidae) from the Taieri River, southern New Zealand. J. R. Soc. N. Z. 1997, 27, 199-217. [CrossRef]

28. McDowall, R.M.; Chadderton, W.L. Galaxias gollumoides (Teleostei : Galaxiidae), a new fish species from Stewart Island, with notes on other non-migratory freshwater fishes present on the island. J. R. Soc. N. Z. 1999, 29, 77-88. [CrossRef]

29. Waters, J.M.; Rowe, D.L.; Burridge, C.P.; Wallis, G.P. Gene trees versus species trees: Reassessing life-history evolution in a freshwater fish radiation. Syst. Biol. 2010, 59, 504-517. [CrossRef]

30. McDowall, R.M. New Zealand Freshwater Fishes: A Natural History and Guide; MAF Publishing Group: Auckland, New Zealand, 1990.

31. Waters, J.M.; Craw, D.; Youngson, J.H.; Wallis, G.P. Genes meet geology: Fish phylogeographic pattern reflects ancient, rather than modern, drainage connections. Evolution 2001, 55, 1844-1851. [CrossRef]

32. Craw, D.; Upton, P.; Burridge, C.P.; Wallis, G.P.; Waters, J.M. Rapid biological speciation driven by tectonic evolution in New Zealand. Nat. Geosci. 2016, 9, 140-144. [CrossRef]

33. Craw, D.; King, T.M.; McCulloch, G.A.; Upton, P.; Waters, J.M. Biological evidence constraining river drainage evolution across a subduction-transcurrent plate boundary transition, New Zealand. Geomorphology 2019, 336, 119-132. [CrossRef]

34. Waters, J.M.; Craw, D.; Burridge, C.P.; Kennedy, M.; King, T.M.; Wallis, G.P. Within-river genetic connectivity patterns reflect contrasting geomorphology. J. Biogeogr. 2015, 42, 2452-2460. [CrossRef]

35. Dunn, N.; Allibone, R.; Closs, G.; Crow, S.; David, B.; Goodman, J.; Griffiths, M.; Jack, D.; Ling, N.; Waters, J. , et al. Conservation Status of New Zealand Freshwater Fishes, 2017; Department of Conservation: Wellington, New Zealand, 2018.

36. Allibone, R.; David, B.; Hitchmough, R.; Jellyman, D.; Ling, N.; Ravenscroft, P.; Waters, J. Conservation status of New Zealand freshwater fish, 2009. N. Z. J. Mar. Freshwat. Res. 2010, 44, 271-287. [CrossRef]

37. Carrea, C.; Anderson, L.V.; Craw, D.; Waters, J.M.; Burridge, C.P. The significance of past interdrainage connectivity for studies of diversity, distribution and movement of freshwater-limited taxa within a catchment. J. Biogeogr. 2014, 41, 536-547. [CrossRef]

38. McLaren, S.; Wallace, M.W.; Gallagher, S.J.; Miranda, J.A.; Holdgate, G.R.; Gow, L.J.; Snowball, I.; Sandgren, P. Palaeogeographic, climatic and tectonic change in southeastern Australia: The Late Neogene evolution of the Murray Basin. Quat. Sci. Rev. 2011, 30, 1086-1111. [CrossRef]

39. McCulloch, G.A.; Wallis, G.P.; Waters, J.M. Onset of glaciation drove simultaneous vicariant isolation of alpine insects in New Zealand. Evolution 2010, 64, 2033-2043. [CrossRef] 
40. Kreger, K.M.; Shaban, B.; Wapstra, E.; Burridge, C.P. Phylogeographic parallelism: Concordant patterns in closely related species illuminate underlying mechanisms in the historically glaciated Tasmanian landscape. J. Biogeogr. 2020, in press. [CrossRef]

41. Craw, D.; Waters, J. Geological and biological evidence for regional drainage reversal during lateral tectonic transport, Marlborough, New Zealand. J. Geol. Soc. 2007, 164, 785-793. [CrossRef]

42. Knowles, L.L.; Maddison, W.P. Statistical phylogeography. Mol. Ecol. 2002, 11, 2623-2635. [CrossRef]

43. Townsend, C.R. Invasion biology and ecological impacts of brown trout Salmo trutta in New Zealand. Biol. Conserv. 1996, 78, 13-22. [CrossRef]

44. Waters, J.M. Competitive exclusion: phylogeography's 'elephant in the room'? Mol. Ecol. 2011, 20, 4388-4394. [CrossRef] [PubMed]

45. Waters, J.M.; Fraser, C.I.; Hewitt, G.M. Founder takes all: Density-dependent processes structure biodiversity. Trends Ecol. Evol. 2013, 28, 78-85. [CrossRef] [PubMed]

46. Burridge, C.P.; Craw, D.; Fletcher, D.; Waters, J.M. Geological dates and molecular rates: Fish DNA sheds light on time dependency. Mol. Biol. Evol. 2008, 25, 624-633. [CrossRef]

(C) 2020 by the authors. Licensee MDPI, Basel, Switzerland. This article is an open access article distributed under the terms and conditions of the Creative Commons Attribution (CC BY) license (http://creativecommons.org/licenses/by/4.0/). 